\title{
ANALISIS PENGARUH INOVASI PRODUK, ORIENTASI PASAR, KEUNGGULAN BERSAING TERHADAP KINERJA PEMASARAN DI SENTRA INDUSTRI MEBEL DESA SEMBUNGAN
}

\author{
Miftakhul Amin, ${ }^{1}$ Sudarwati, ${ }^{2}$ Siti Maryam ${ }^{3}$ \\ Universitas Islam Batik Surakarta \\ miftaaamen@gmail.com
}

\begin{abstract}
Abstrak : Penelitian ini bertujuan untuk mengetahui pengaruh inovasi produk, orientasi pasar, keunggulan bersaing terhadap kinerja di sentra industri mebel kayu desa Sembungan. Jenis penelitian menggunakan metode deskriptif kuantitaif. Populasi dari penelitian ini adalah keseluruhanpengrajin kayu di desa Sembungan dengan menggunakan random sampling sebagai teknik pengambilan sampelnya. Variabel dependen $(Y)$ dalam penelitian ini adalah kinerja pemasaran. Variabel independen $(X)$ meliputi: inovasi produk (X1) orientasi pasar (X2) dan keunggulan bersaing (X3). Metode analisis data menggunakan regresi linier berganda. Sedangkan untuk program jika data menggunakan IBM SPSS 21.0 statistik. Hasil analisis menunjukan bahwa terdapat pengaruh secara simultan dan signifikan variabel inovasi produk, orientasi pasar, keunggulan bersaingterhadap kinerja pemasaran. Variabel inovasi produk berpengaruh secara parsial terhadap kinerja pemasaran.Orientasi pasar tidak berpengaruh terhadap kinerja pemasaran.Keunggulan bersaing berpengaruh secara parsial terhadap kinerja pemasaran. Model regresi dalam penelitian ini adalah $Y=29,664+(-0,680)+(-0,225)+0,506+e$. Hasil koefisien determinasi menunjukkan inovasi produk, orientasi pasar, keunggulan bersaing memiliki pengaruh sebesar $61.2 \%$ terhadap kinerja pemasaran di sentra industri mebel kayu desa Sembungan.
\end{abstract}

Keyword: Kinerja Pemasaran, Inovasi Produk, Orientasi Pasar, Keunggulan Bersaing

\section{PENDAHULUAN}

Seiring perkembangan perekonomian dan teknologi yang semakin maju, perusahaan dituntut aga rlebih meningkatkan hasil produksi dan mutu produk yang dihasilkan. Persaingan dalam dunia industri mendorong perusahaan untuk mengatur strategi yang tepat untuk memasarkan produk usahanya, tidah hanya perusahaan besar saja namun pada usaha kecil dan menengah mereka juga selalu mengatur strategi pemasarannya agar kinerja pemasaran baik dan menguntungkan perusahaan

Kinerja pemasaran berasal dari usaha dana aktifitas proses pemasaran secara menyeluruh dari perusahaan atau organisasi itu sendiri. Kinerja pemasaran dapat dipandang dari sejauh mana perusahaan itu menciptakan sebuah prestasi yang didapat perusahaan melalui produk yang dihasilkanya. Kinerja pemasaran berkaitan dengan pertumbuhan pelangganya itu meningkatnya pelanggan yang melakukan pembelian kembali ke pada produk yang dihasilkan.

Inovasi poduk mampu dijadikan sebagai strategi untuk meningkatkan kinerja pemasaran, Persaingan dalam dunia industri tidak hanya mengenai harga dan kualitas produk, namun juga inovasi produk yang digunakan sebagai strategi pemasaran agar kinerja pemasaran meningkat dan perusahaanj uga memiliki kesempatan lebih maju dan unggul dari pesaingnya karena perusahaan dapat mengetahui apa yang diinginkan oleh pasarnya. 
Orientasi pasar dilakukan oleh perusahaan merupakan aktifitas yang bertujuan untuk memberikan kepuasan pada konsumen karena perusahaan menganggap konsumen sebagai kiblat dalam menjalankan bisnis.

Keunggulan bersaing harus dimiliki perusahaan untuk meningkatkan kinerja pemasaran yang dapat dilakukan dengan salah satu caranya yaitu menginovasi produk, perusahaan yang memiliki keunggulan bersaing sudah pasti mempunyai produk bercirikhas dan tidak dimiliki oleh para pesaingnya.

\section{TINJAUAN PUSTAKA}

A. Kinerja Pemasaran

Kinerja pemasaran adalah sebuah ukuran hasil kerja yang diperoleh dari kegiatan pemasaran pada suatu perusahaan. Kinerja merupakan sebuah konsep tentang pemahaman yang cukup luas, dan perubahan yang sama sesuai perspektif dan kebutuhan pengguna. Strategi perusahaan yang di terapkan bertujuan untuk menghasilkan kinerja pemasaran seperti volume penjualan dan tingkat pertumbuhan penjualan yang baik (Alrubaiee,2013:5)

1) Manfaat Kinerja Pemasaran.

a. Meningkatkan kemampuan untuk kepuasan konsumen.

b. Pengetahuan dan kemampuan organisasi.

c. Dampak terhadap reputasi perusahaan.

2) Faktor-faktor yang mempengaruhi kinerja pemasaran.

a. Pertumbuhanpelangganadalahtingkatpertumbuhanyangberhasildicapaiolehperusahaan

b. Pangsa pasar adalah bagian pasar yang mana satu perushaan menguasai seluruh potensi penjualan.

c. Pertumbuhanpenjualanadalahtingkatpertumbuhanyangberhasildijual.

d. Pertumbuhan keuangan adalah banyaknya laba yang dapat dicapai perusahaan dalam satu produk yang dihasilkanya

\section{B. Inovasi Produk}

Inovasi Produk adalah keseluruhan proses yang dimulai dari ide baru, penemuan baru dan pengembangan dari suatu pasar baru yang saling mempengaruhi antara satu dengan lainnya. Hasil dari sebuah pengenalan cara baru berupa inovasi berdampak perubahan yang sangat besar dalam membandingkan uji nilai guna dari manfaat sebuah produk yang dihasilkan perusahaan dan harga yang di tetapkan oleh produsen.(Kotler, 2016:454)

1) Jenis-Jenis Inovasi Produk

a. InovasiaProduk Baru yaitu sebuah produk dan jasa yang belum pernah ada.

b. Inovasi Pengembangan Produk yaitu pengembangan terhadap sebuah produk dan jasa yang sudah ada.

2) Faktor-Faktor Yang Mempengaruhi Inovasi Produk

a. Permintaan yang memadai.

b. Produk sesuai dengan struktur pemasaran yang ada.

c. Produk baru lebih utama dan lebih menguntungkan.

d. Kemampuan keuangan yang ada.

e. Kemampuan yang tidak melanggar hukum.

f. Adanya kemampuan mnajemen yang memadai untuk menangani. 
3) Cara Agar Produk Dari Inovasi Memiliki Ciri Khas

a. Meningkatkan kegunaan produk.

b. Menemukan pengguna produk yang baru.

c. Berani memasuki pasar baru.

d. Mengubah positioning merek.

e. Menambah kegunaan produk

f. Memperluas produk dengan merek yang sama pada produk yang lain

4) Tipe Inovasi Produk

a. Baru dari persepsi perusahaan

Produk dapat dikatakan baru apabila produk yang dihasilkn tersebut benar-benar baru dilahirkan oleh perusahaan dan tidak sama dengan produk-produk yang sudah diluncurkan sebelumnya.

b. Baru dari persepsi perusahaan

Persepsi ini perilaku konsumen lebih berpengaruh dalam menekankan aksesoris yang ada pada produk tersebut.

c. Baru dari persepsi konsumen

Baru menurut konsumen jika barang yang ditawarkan memiliki manfaat penggunaan dan harga yang berbeda dari produk yang sudah ada. Hal yang penting dan darus diperhatikan oleh perusahaan adalah perspektif konsumen karena dapat mempengaruhi jumlah pembelian produk tersebut.

C. Orientasi Pasar

Orientasi pasar adalah suatu aktivitas yang berhubungan dengan konsep pemasaran seperti menilai kebutuhan dan keinginan pelanggan (Tjiptono, 2012: 31)

1. Strategi pemasaran yang berorientasi pasar memiliki tiga konsep yang harus mengacu pada:

a. Lebih fokus kepada konsumen yang memiliki kemauan dan keinginan, sehingga perusahaan mampu membedakan mana produk yang ditawarkan dan mana produk yang ditawarkan oleh pesaing.

b. Bertanggung jawab atas kebijakan konsumenya dalam hal kebutuhan dan keinginan secara hukum, pencapaian tujuan tersebut menjadikan rasa kepuasan bagi pelanggan dlam jangka panjang.

c. memfokuskan seluruh aktifitas yang dilakukan di perusahaan termasuk inovasi produk untuk menguntungkan, memuasakan kebutuhan konsumen.

2. Penggunaan Konsep Pemasartan Sangatlah Penting Dan Menjadi Pedoman Agar Bisnis Yang Dijalankanya Menjadi Lebih Konsep Maju Pemasaran:

a. Kebutuhan dan keinginan konsumen menjadi dasar tujuan bisnis.

b. Melakukan pendekatan yang bertujuan ingin memuaskan kebutuhan dan keinginan konsumen.

c. Mencapai tujuan yang ingin di berikan kepada konsumen melalui kepuasan pelanggan atau konsumen.

3. Manfaat Orientasi Pasar

a. Membantu perusahaan dalam memproduksi suatu produk yang sesui dengan persepsi pelangganya.

b. Membantu dalam proses pembuatan secara efisien.

c. Membantu mengetahui perbedaan dari pencapaian suatu perusahaan. 
d. Membantu perusahaan agar memiliki arah competitive adventage.

D. Keunggulan Bersaing

Keunggulan bersaing merupakan suatu kelebihan yang dimiliki oleh perusahaan seperti harga lebih murah, memberikan banyak manfaat untuk produk dengan harga mahal, pada intinya keunggulan yang melebihi para pesaingnya.(Kotler dan Amstrong, 2011: 211)

1. Jenis Dasar Keunggulan Dalam Bersaing

Fauzi (2015: 87) berpendapat bahwa dalam keunggulan bersaing memiliki dua jenis dasar keunggulan, yaitu

a. Biaya Rendah, perusahaan melakukan strategi dengan biaya rendah untuk menghasilkan produk baik barang ataupun jasa.

b. Deferensiasi, perusahaan mampu menghasilkan produk unik yang tidak dimiliki pesaing namun dapat diterima oleh konsumen

2. Tujuan Keunggulan Bersaing

Kotler \& Amstrong, (2012: 29) berpendapat bahwa selain keuntungan strategi keunggulan bersaing memiliki beberapa tujuan lain, yaitu :

a. Membentuk positioning yang tepat

b. Mempertahankan loyalitas pelanggan

c. Mendapatkan pangsa pasar baru

d. Memaksimalkan penjualan

e. Menciptakan kinerja bisnis yang efektif

\section{METODE PENELITIAN}

Jenisa penelitian ini menggunakan metode deskriptif dan kuantitatif. Populasi dalam penelitian ini adalah seluruh pengrajin mebel kayu desa Sembungan dengan menggunakan tehnik Proportionate stratified random sampling yaitu metode Pengambilan penentuan sampelnya memperhatikan strata (tingkatan) yang ada dalam populasi Sugiyono (2010:217).Sampel yang diambil sebanyak 80 responden. Metode analisis data yang digunakan adalah regresi linier berganda.

\section{ANALISIS DAN PEMBAHASAN}

\section{A. Analisis Data}

1. Uji Validitas

Uji validitas dilakukan kepada seluruh butir pertanyaan dengan mengkorelasi sekor setiap butir pertanyaan dengan skor total. Jika $r_{\text {hitung }}>$ dari $r_{\text {tabel }}$ maka pertanyaan tersebut dinyatakan valid dan jika $r_{\text {hitung }}$ lebih kecil dari $r_{\text {tabel }}$ maka pertanyaan tersebut dinyatakan tidak valid. Hasil uji validitas setiap variable dijelaskan sebagai berikut

\begin{tabular}{|c|c|c|}
\hline Butir Pertanyaan & Total Pearson Correlation & Keterangan \\
\hline Kinerja Pemasaran & & \\
Pertanyaan 1 & 0.756 & Valid \\
Pertanyaan 2 & 0.698 & Valid \\
Pertanyaan 3 & 0.727 & Valid \\
Pertanyaan 4 & 0.736 & Valid \\
Pertanyaan 5 & 0.658 & Valid \\
\hline
\end{tabular}




\begin{tabular}{|c|c|c|}
\hline Inovasi Produk & 0.716 & Valid \\
Pertanyaan 1 & 0.847 & Valid \\
Pertanyaan 2 & 0.854 & Valid \\
Pertanyaan 3 & 0.780 & Valid \\
Pertanyaan 4 & 0.646 & Valid \\
Pertanyaan 5 & & \\
\hline Orientasi Pasar & 0.739 & Valid \\
Pertanyaan 1 & 0.795 & Valid \\
Pertanyaan 2 & 0.767 & Valid \\
Pertanyaan 3 & 0.789 & Valid \\
Pertanyaan 4 & 0.622 & Valid \\
Pertanyaan 5 & 0.649 & \\
\hline Keunggulan Bersaing & 0.685 & Valid \\
Pertanyaan 1 & 0.726 & Valid \\
Pertanyaan 2 & 0.791 & Valid \\
Pertanyaan 3 & 0.675 & Valid \\
Pertanyaan 4 & & Valid \\
Pertanyaan 5 & & \\
\hline
\end{tabular}

2. Uji Reliabilitas

Uji reliabilitas digunakan untuk menguj isejauh mana sebuah alat pengukur dapat dipercaya dan diandalkan jika suatu saat dilakukan pengujian dua kali atau lebih dan hasil nya tetap konsisten. Pengujian reliabilitas dengan menggunakan ujistatistik cronbach alpha. Suatu variabel dikatakan reliable jika nilai cronbach alpha $>0,06$. Hasil uji reliabilitas secara singkat di tunjukan pada tabel:

\begin{tabular}{|c|c|c|c|}
\hline Variabel & R11 & CronbachAlpha & Keterangan \\
\hline $\begin{array}{c}\text { Kinerja } \\
\text { Pemasaran }\end{array}$ & 0,752 & 0,60 & Reliabela \\
\hline InovasiProduk & 0,810 & 0,60 & Reliabela \\
\hline Orientasi Pasar & 0,757 & 0,60 & Reliabela \\
\hline $\begin{array}{c}\text { Keunggulan } \\
\text { Bersaing }\end{array}$ & 0,723 & 0,60 & Reliabela \\
\hline
\end{tabular}

3. Uji Normalitas

Hasil pengujian kolmogorof-smirnov-test menunjukan bahwa nilai a symp.Sig (2-tailed lebih dari 0.05 (0.887 >0.05) menunjukan bahwa model regresi layak digunakan karena memenuhi asumsi normalitas atau dapat dikatakan data penelitian terdistribus inormal.

4. Uji Multikolinearitas

Alat untuk menguji korelasi antar variabel independen dengan membaca nilaitolerance $>0,10$ dannilaiVIF $<10$. Hasiluji multikolieritas disajikan dalam tabel berikut:

\begin{tabular}{|c|c|c|c|}
\hline Variabel & Tolerance & VIF & Keterangan \\
\hline Inovasi Produk & 0,888 & 1,126 & TidakTerjadi \\
\hline
\end{tabular}




\begin{tabular}{|c|c|c|c|}
\hline & & & Multikolinearitas \\
\hline Orientasi Pasar & 0,878 & 1,139 & $\begin{array}{c}\text { TidakTerjadi } \\
\text { Multikolinearitas }\end{array}$ \\
\hline $\begin{array}{c}\text { Keunggulan } \\
\text { Bersaing }\end{array}$ & 0,970 & 1,031 & $\begin{array}{c}\text { TidakTerjadi } \\
\text { Multikolinearitas }\end{array}$ \\
\hline
\end{tabular}

Tabel tersebut

menunjukan bahwa masing-masing variable memiliki nilai $\mathrm{VIF}<10,0$ dan nilai tolerance $>0,10$. Hasil dari perhitungan model regres menunjukan bahwa tidak adanya masalah multikolinearitas, sehingga memenuhi syarat analisisregresia.

5. Uji Heterokedastisitas

Pengujian heterokedastisitas menggunakan uji glejser, jika tingkat signifikan berada diatas 0,05 artinya tidak terjadi heterokedastisitas namun apabila berada dibawah 0,05 artinya terjadi heterokedastisitas. Hasil ujia heteroskedastisitas dapat dilihat pada tabel.

\begin{tabular}{|c|c|c|c|}
\hline Variabel & Sig & Batas & Keterangan \\
\hline Inovasi & 0,94 & $a \geq 0,0$ & TidakTerjadi \\
Produk & 6 & 5 & Heteroskedastisitas \\
\hline Orientasi & 0,98 & $a \geq 0,0$ & TidakTerjadiHeteroskedastisita \\
Pasar & 9 & 5 & s \\
\hline Keunggula & 0,92 & $a \geq 0,0$ & TidakTerjadi \\
n Bersaing & 2 & 5 & Heteroskedastisitas \\
\hline
\end{tabular}

Dari data diatas masing-masing variable memiliki nilai signifikan $>0,05$ maka dapat disimpulkan setiap variable tidak terjadi heteroskedastisitas, sehingga memenuhi syarat dalam analisis regresi.

\section{B. Uji Regresi Linier Berganda}

Analisis regresi berganda adalah model untuk mengetahui pengaruh variable independen yaitu inovasi produk, orientasi pasar, keunggulan bersaing terhadap kinerja pemasaran.

\begin{tabular}{|c|c|c|}
\hline \multirow{2}{*}{ Model } & \multicolumn{2}{|c|}{ Unstandardized Coefficients } \\
\cline { 2 - 3 } & $\mathrm{B}$ & Std.Eror \\
\hline 1. (Constantant) & 29,664 & 4,229 \\
\hline Inovasi Produk & $-0,680$ & 0,083 \\
\hline Orientasi Pasar & $-0,225$ & 0,112 \\
\hline Keunggulan Bersaing & 0,506 & 0,105 \\
\hline
\end{tabular}
berikut:

Berdasarkan tabel di ats dapat diketahui persamaan regresi linier berganda adalah sebagai

$$
\mathrm{Y}=29,664+(-0,680)+(-0,225)+0,506+\mathrm{e}
$$

Maka dari persmaan regresi linier berganda yang terbentuk di atas dapat diinterpretasikan sebagai berikut:

Nilai konstanta bernilai positif sebesar 29,664 artinya apabila variabel inovasi produk, orientasi pasar, dan keunggulan bersaing konstan, makakinerja pemasaran mengalami peningkatan sebesar 29,664. Nilai variabel inovasi produk X1 negatif sebesar -0,680 hal ini menunjukan bahwa variabel inovasi produk berpengaruh negatif dan signifikan terhadap kinerja pemasaran.Nilai variabel orientasi pasar X2 negatif sebesar -0,225 hal ini menunjukan bahwa variabel orientasi 
pasar tidak berpengaruh secara signifikan terhadap kinerja pemasaran. Artinya variabel orientasi pasar tidak mempengaruhi peningkatan kinerja pemasaran.nilai variabel keunggulan bersaing X3 positif sebesar 0,506 hal ini menunjukan bahwa variabel keunggulan bersaing berpengaruh positif dan signifikan terhadap kinerja pemasaran.Artinya semakin tinggi keunggulan bersaing maka semakin tinggi pula kinerja pemasaran.

Koefisien determinan $\left(\mathbf{R}^{2}\right)$

\begin{tabular}{|c|c|c|}
\hline $\mathrm{R}$ & RSquare & AdjustedRSquare \\
\hline 0,782 & 0,612 & 0,596 \\
\hline
\end{tabular}

Dari data di atas, dapat diketahui bahwa koefisien determinasi (Adjusted $R$ Square) yang diperoleh sebesar 0,596. Hal ini menunjukkan bahwa variabel inovasi produk,orientasi pasar dan keunggulan bersaing mempengaruhi kinerja pemasaran sebesar 59.6\% terhadap kinerja pemasaran. Sedangkan sisanya $40.4 \%$ kinerja pemasaran dapat dipengaruhi oleh variabel lain yang tidak dimasukkan dalam model analisis penelitian ini.

Uji F

\begin{tabular}{|c|c|c|c|c|}
\hline Variabel & $\mathrm{F}_{\text {hitung }}$ & $\mathrm{F}_{\text {tabel }}$ & Sig & Keterangan \\
\hline $\begin{array}{c}\text { Regression Residual } \\
\text { Total }\end{array}$ & 39,919 & 3.20 & 0,000 & $\begin{array}{c}\mathrm{H}_{0} \text { ditolak } \mathrm{H}_{1} \\
\text { diterima }\end{array}$ \\
\hline
\end{tabular}

Data uji ANOVA atau $F$ test diperoleh $\mathrm{f}_{\text {hitung }}$ sebesar $39.919>\mathrm{F}_{\text {tabel }}$ sebesar 3.20 dengan probabilitas sebesar 0,000. Karna nilai probabilitas $<0,05$, maka modelregresi dapat digunakan untuk memprediksi kinerja pemasaran atau dapat dikatakan bahwa variabel inovasi produk,orientasi pasar,dan keunggulan bersaing secara bersama-sama berpengaruh terhadap kinerjaa pemasaran.

Uji T

\begin{tabular}{|c|c|c|c|}
\hline Variabel & $\mathrm{t}_{\text {hitung }}$ & $\mathrm{t}_{\text {tabel }}$ & $\mathrm{Sig}$ \\
\hline Inovasi produk & -8.152 & 1,992 & 0.000 \\
\hline Orientasi pasar & -2.006 & 1,992 & 0.048 \\
\hline Keunggulan bersaing & 4.813 & 1,992 & 0.000 \\
\hline
\end{tabular}

Dari data di atas, maka diperoleh hasil analisis Variabel inovasi produk memiliki nilai thitunga $8,152>$ dari $t_{\text {tabel }}-1,992$, dan nilai signifikansi sebesar $0,000<0,05$ bertanda negatif, yang artinya bahwa variabel inovasi produk berpengaruh secara negatif dan signifikanterhadapkinerja pemasaran. Variabel orientasi pasar memiliki nilai $t_{\text {hitung }}-2,006>$ dari $t_{\text {tabel }}-1,992$ dan nilai signifikansi sebesar0,048<0,05bertanda negativ, yang artinya bahwa variabel orientasi pasar berpengaruh secara negatif dan signifikan terhadap kinerja pemasaran.Variabel keunggulan bersaing memiliki nilai $t_{\text {hitung }} 4,813>$ dari $t_{\text {tabel }} 1,992$ dan nilai signifikansi sebesar $0,000<0,05$ bertanda positif, yang artinya bahwa variabel keunggulan bersaing berpengaruh secara positif dan signifikan terhadap kinerja pemasaran.

\section{Pembahasan}

Berdasarkan penelitian tentang“ analisis pengaruh inovasi produk, orientasi, dan keunggulan bersaing terhadap kinerja pemasaran di sentral industri mebel desa sembungan " diperoleh sebagai berikut: 
1. Pengaruh inovasi produk terhadap kinerja pemasaran.

Hasil penelitian ini menunjukan bahwa variabel inovasi produk memiliki nilai $t_{\text {hitung }}$ sebesar $-8,152>$ dari $t_{\text {tabel}}-1,992$ dengan nilai probabilitas sebear0,000berarti lebih kecil dari 0,05maka $\mathrm{H}_{1}$ diterima, yang artinya ada pengaruh negatif dan signifikan terhadap kinerja pemasaran. Hal ini dikarenakan pada industri mebel produknya digunakan dalam jangka panjang sehingga konsumen tidak akan melakukan pembelian produk mebel selama produk yang dimiliki belum rusak, jadi apabila dilakukan inovasi produk secara terus menerus mengakibatkan kinerja pemasaran menurun.

Menurut Manahera, Moniharapon, Tawas (2018) dengan judul analisis pengaruh orientasi pasar, orientasi kewirausahaan terhadap inovasi produk dan kinerja pemasaran (study kasus umkm nasi kuning di manado) menyimpulkan secara parsial inovasi produk berpegaruh negatif terhadap kinerja pemasaran di umkm nasi kuning di manado.

Hasil penelitian ini sejalan dengan hasil penelitian yang dilakukan oleh Mandey Dan Salindeho (2018) yang berjudul Pengaruh Inovasi Produk, Tempat Dan Promosi Terhadap Kinerja Pemasaran Motor Suzuki (Pada PT. Sinar Galesong Mandiri Cab.Malalayang) menyimpulkan bahwa Secara parsial Inovasi Produk berpengaruh negatif dan signifikan terhadap Kinerja Pemasaran pada PT. Sinar Galesong Mandiri cabang Malalayang

2. Pengaruh orientasi pasar aterhadapa kinerja pemasaran

Hasil penelitian ini menunjukan bahwa variabel orientasi pasar memiliki nilai $t_{\text {hitung }}$

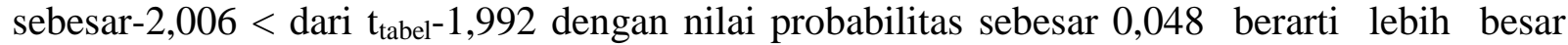
dari 0,05 maka $\mathrm{H}_{1}$ ditolak, yang artinyaada pengaruh negatif dan signifikan terhadap kinerja pemasaran.Hal ini dikarenakan pengrajin hanya menggunakan kayu sebagai bahan produksi sehingga produk mebel yang dihasilkan bersifat monoton yang menyebabkan konsumen merasa bosan dengan produk produk tersebut dan mengakibatkan kinerja pemasaran menurun Hasil penelitian ini tidak sejalan dengan hasil penelitian sebelumnya yang dilakukan oleh Guspul (2016) yang berjudul Pengaruh Orientasi Pasar, Inovasi Dan Orientasi Kewirausahaan Terhadap Kinerja Pemasaran Umkm "Batako" Di Kepil Wonosobo yang menyimpulkan bahwa variabel orientasi pasar berpengaruh signifikan terhadap kinerja pemasaran. Karena jika industri mebel kayu ingin meningkatkan kinerja pemasaran melalui orientasi pasar maka pengrajin harus melakukan survei pasar dengan melihat apa yang diminati oleh konsumen serta memberikan pelayanan yang baik, lalu mengumpulkan dan mengamati perkembangan pesaing yang dilakukan pasar.

3. Pengaruh keunggulan bersaing terhadap kinerja pemasaran

Hasil penelitian ini menunjukkan bahwa variabel keunggulan bersaing memiliki nilai $t_{\text {hitung }}$ sebesar 4,813 $\geq \mathrm{t}_{\text {tabel }} 1,992$ dengan nilai probabilitas sebesar 0,000 berarti lebih kecil 0,05 maka $\mathrm{H}_{0}$ ditolak, artinya terdapat pengaruh yang signifikanterhadap kinerja pemasaran. Harga yang lebih murah dari pesainnya akan meningkatkan keunggulan bersaing seperti memberikan diskon kepada konsumen saat pembelin berikutnya, memiliki produk yang berciri khusus agar tidak mudah ditiru seperti dengan memberikan ciri khusus pada produk yang dibuat pesaing tidak mudah meniru produk yang di jual laku di pasaran, menawarkan produk yang lebih murah dari yang lebih berkualitas tinggi dari pada pesaingnya seperti pengrajin selalu melakukan musyawarah bersama konsumen untuk menentukan bahan mana yang akan di gunakan pada produk yang akan di pesan dan di buat oleh konsumen, menampilkan produk yang berbeda dari pesaingnya 
Menurut Fatmawati (2016) yang berjudul Pengaruh Orientasi Pasar, Orientasi Kewirausahaan Terhadap Keunggulan Bersaing Dan Kinerja Pemasaran menyimpulkan bahwa bahwa ada pengaruh yang positif dan signifikan keunggulan bersaing terhadap kinerja pemasaran.

Hasil penelitian ini sejalan dengan hasil penelitian yang dilakukan oleh Hajar dan Sukaatmadja (2016) yang berjudul Peran Keunggulan Bersaing Memediasi Pengaruh Orientasi Kewirausahaan Terhadap Kinerja Pemasaran yang menyatakan bahwa variabel keunggulan bersaing berpengaruh positif dan signifikan terhadap kinerja pemasaran.

\section{KESIMPULAN DAN SARAN}

\section{Kesimpulan}

Dari hasil penelitian dengan judul "Analisis Pengaruh Inovasi Produk, Orientasi Pasar Dan Keunggulan Bersaing Terhadap Kinerja Pemasaran Di Sentra Industri Mebel Kayu Desa Sembungan Kecamatan Nogosari Kabupaten Boyolali”, maka dapat disimpulkan sebagai berikut:

1) Inovasi produk berpengaruh negatif dan signifikan terhadap kinerja pemasaran pada sentra industry mebel kayu di Desa Sembungan Kecamatan Nogosari Kabupaten Boyolali. Hal ini ditunjukkan dengan nilai $t_{\text {hitung }}-8,152>\mathrm{t}_{\text {tabel }}-1,992$ dan nilai signifikansi $0,000<0,05$.

2) Orientasi pasar berpengaruh negatif dan signifikan terhadap kinerja pemasaran pada sentra industri mebel kayu di Desa Sembungan Kecamatan Nogosari Kabupaten Boyolali. Hal ini ditunjukkan dengan nilait hitung $-2,006>\mathrm{t}_{\text {tabel }}-1,992$ dan nilai signifikansi $0,048<0,05$.

3) Keunggulan bersaing berpengaruh positif signifikan terhadap kinerja pemasaran pada sentra industri mebel kayu di Desa Sembungan Kecamatan Nogosari Kabupaten Boyolali. Hal ini ditunjukkan dengan nilai $t_{\text {hitung }} 4,813>\mathrm{t}_{\text {tabel }} 1,992$ dan nilai signifikansi $0,000<0,05$.

4) Penelitian ini hanya menguji pengaruh inovasi produk, orientasi pasar,dan keunggulan bersaing terhadap kinerja pemasaran. Terbukti dari nilai $R$ square sebesar $59.6 \%$ terhadap kinerja pemasaran. Sedang kansisanya $40.4 \%$ kinerja pemasaran dapat dipengaruhi oleh variabel lain yang tidak dimasukkan dalam model analisis penelitian ini

\section{Saran}

Berdasarkan kesimpulan dan keterbatasan yang ada dalam penelitian ini, maka dapat dikemukakan beberapa saran sebagai berikut:

1) Penelitian selanjutnya diharapkan untuk mengembangkan variabel-variabel penelitian diluar model penelitian.

2) Diharapkan untuk penelitian selanjutnya semakin memperluas penelitian dengan melakukan penelitian yang serupa pada tempat atau lokasi yang sama dengan variabel yang berbeda. 


\section{DAFTAR PUSTAKA}

Alrubaiee, L. (2013), "Menjelajahi Hubungan antara Perilaku Penjualan Etis, Kualitas Hubungan, dan Loyalitas Pelanggan", Jurnal Internasional Pemasaran Studie, Vol.4 (1), hal: 7-21

HajarSiti,Putu Gde Sukaatmadja. 2016. Peran Keunggula Bersaing Memediasi

Pengaruh Orientasi Kewirausahaan Terhadap Kinerja Pemasaran. Vol.5.No.10. hal 6580-6609. ojs.unud.ac.id

Kotler, Philip and Gary Amstrong. 2016. Prinsip-prinsip Pemasaran. Edisi 13. Jilid 1.Jakarta: Erlangga

Kotler,Philip and Gary Armstrong, 2012. Prinsip-prinsip Pemasaran. Edisi 13 Jilid 1, Jakarta: Erlangga

Kotler. Phillip dan Amstrong.(2011). Manajemen Pemasaran. Jilid 2, Jakarta. Bumi Aksara.

Muchammad Fauzi, Manajemen Strategik, Semarang: CV. Karya Abadi Jaya.2015,1-2

Manahera Marta Marsela, Silcyljeova Moniharapon, Hendra N. Tawas .2017. Analisis Pengaruh Orientasi Pasar, Orientasi Kewirausahaan Terhadap Inovasi Produk Dan Kinerja Pemasaran (Studi Kasus Umkm Nasi Kuning Di Manado). Vol.06,No.04.2737. jurnal EMBA

Sugiyono. 2010. Metode Penelitian Pendidikan Pendekatan Kuantitatif, kualitatif, dan R\&D. Bandung: Alfabeta

Salindeho Angelita Elisabeth, Silvya L. Mandey.2018. Pengaruh Inovasi Produk, Tempat Dan Promosi Terhadap Kinerja Pemasaran Motor Suzuki (Pada PT. Sinar Galesong Mandiri Cab.Malalayang) .Vol.06.No.04.3348.jurnalEMBA

Tjiptono, Fendy. 2011. Service Quality \& Satisfaction. Yogyakarta: CV Andi Offset. 